\title{
Communicative Approach in Teaching Afro-Asian Literature and Performance of Grade 8 Students
}

\author{
Almie Ocampo Ballesteros ${ }^{1}$, Cristobal Millenes Ambayon ${ }^{2, *}$ \\ ${ }^{1}$ Department of Education, Telafas National High School, Telafas, Columbio, Philippines \\ ${ }^{2}$ College of Teacher Education, Sultan Kudarat State University, Administration Center Central Educational Site and Services (ACCESS) \\ Campus, Tacurong City, Philippines
}

Email address:

earlea1426@gmail.com (A. O. Ballesteros),jophkris_01@yahoo.com (C. M. Ambayon)

${ }^{*}$ Corresponding author

\section{To cite this article:}

Almie Ocampo Ballesteros, Cristobal Millenes Ambayon. Communicative Approach in Teaching Afro-Asian Literature and Performance of Grade 8 Students. Education Journal. Vol. 9, No. 6, 2020, pp. 173-178. doi: 10.11648/j.edu.20200906.14

Received: November 17, 2020; Accepted: December 3, 2020; Published: December 28, 2020

\begin{abstract}
The world constant change calls for a more rapid growth in the intellectual and emotional aspect of every individual. English, as a global language requires most of the learners to be more acquainted with the utilization of English language. This paper focused on the use of Communicative Approach in Teaching Afro-Asian Literature and the performance of Grade 8 students. The study tested the acceptability of the instructional module in terms of its content, relevance and instructional quality that turns out to be highly acceptable. The researchers used experimental method of research to the 68 participants who were randomly selected from the Grade 8 students of Telafas National High School and were grouped into experimental and control groups. Findings revealed that students from the control group performed poor in their pre-test and fair in their post-test, while the experimental group performed poor in the pre-test and their performance turned into outstanding after the integration of Communicative Approach. These results were further analyzed with the use of t-test; it statistically showed that there is a significant difference between the mean gain score of the control and experimental group which revealed that the experimental group improved better and learned much on the use of communicative approach than the control group.
\end{abstract}

Keywords: Afro-Asian Literature, Student's Performance, Communicative Approach, Communication Skills

\section{Introduction}

The increasing worldwide call for better communication in the English language has increased meaningfully the concerns of the English language teacher. The English language, as the international language and medium of instruction in the Philippines flows like blood through the veins of the whole nation. To have excellent communicative competence in English is a flaming desire for most people. Communicative competence is more in demand now than ever before considering that the English language is the pillar of learning connecting to other learning areas.

The increasing need for better communication skills in English has shaped a massive plea for English teaching not only in the country but even around the world, as numerous individuals, today want to improve their grasp of English or guarantee that their children achieve a good grip of utilizing English. "The worldwide demand for English has created an enormous claim for quality language teaching and language teaching materials and resources." [12]

Some reserches revealed that "teachers have various perspectives on Communicative Language Teaching depending on their background, training, and practice." [13] The country is now facing a greater dilemma of learners' communication skills considering that they will be the future of the motherland, who will be leading the country, and better communication ability is a prerequisite of it.

For ELT in the Philippines, It was argued that 'rather than focusing on a specific variety of English, the Philippines' school curriculum needs to make a radical move to teach English as it is used in social contexts within the region.' Kirkpatrick refers to this as 'the multilingual model,' combined with the adoption of a 'lingua franca approach to 
the teaching of English.' [8]

In the municipality of Columbio, specifically at Barangay Telafas, very few students can use the English language in discourse and can manipulate the word clearly, wherein, language teachers are significantly facing it, as a challenge on how to uplift the communication ability of the learners. The incongruence between the Communicative Language Teaching conceptual considerations and authentic classroom practices has stimulated the researchers to undertake this research. Stimulated by this perspective, the researchers were motivated and inspired to study the use of the communicative approach in teaching Afro-Asian literature and the students' performance of the Grade 8 students of Telafas National High School.

\section{Conceptual Framework}

The conceptual framework of this study was anchored in the work of [12] "Communicative Language Teaching" stating that "the communicative language teaching is a result from the process of interaction between the learner and the user of the language, collaborative creation of meaning, creating meaningful and purposeful interaction through language."

Communicative Approach paves its way in language study and in teaching as well, as a "reaction against the view of language as a set of structures" [11]. Language study before, primarily focused on language structure, and in connection with teaching language, lingguists give emphasis on grammar usage. It turned out that being knowledgeable in grammar doesn't assure of individual's communicative competence.

Communication does not indicate just making better sentences but utilizing them "to make statements of different kinds, to describe, to record, to classify and so on, or to ask questions, make requests, give orders". As an effect of this, a "reaction towards a view of language as communication, a view in which meaning and the uses to which language plays a central part" (Moon, 2004) has developed. [3] commented that "such events provide whole whole-task practice, improve motivation, allow natural learning, and can create a context which supports education." He further stressed that "if the learners have had enough practice in the part-skills, communicative activities provide a useful opportunity to train the total skill communication in a foreign language."

Some study emphasized that "native speakers often become victims of partial first language acquirement, or they might experience first language attrition due to this lessened interaction to their home language." [10]

In conclusion, it was necessary to stress out that the Communicative Approach often takes the responsibility for doing the tasks on the learners independently. The teacher provides scenarios and offer diverse tasks, so that he can be a facilitator, mentor or guide, but the ultimate task for fulfilling the final task were entrusted on the students.

Therefore, communicative events in the classroom setting was vital in the whole learning process. These scenarios also help the students to establish interpersonal relationships in the learning development. Therefore, a modification towards better and more compassionate learning arenas will be established.

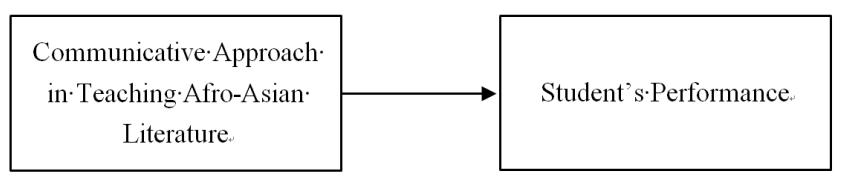

Figure 1. Conceptual Framework of the Study. SKSU, 2019.

\section{Objective and Research Questions}

Generally, this study sought to find the acceptability of Communicative Approach in Teaching Afro-Asian Literature and Performance of Grade 8 Students.

Specifically, it aimed to answer the following questions:

1. What is the extent of acceptability of materials used in the communicative approach in teaching Afro-Asian Literature on the students' performance in terms of:
a. content;
b. relevance; and
c. instructional quality?

2. What is the performance of Grade 8 students in AfroAsian Literature in the control group in the pre-test and post-test results?

3. What is the performance of Grade 8 students in AfroAsian Literature in the pre-test and post-test results of the experimental group?

4. Is there a significant difference between the performance of the control group and experimental group in AfroAsian Literature in their mean gain score?

\section{Research Methodology}

\subsection{Research Design}

The experimental method of research was used in this study. It tested the acceptability of the communicative approach in terms of content, relevance, and instructional quality as well as the performance of the respondents in Afro-Asian Literature.

\subsection{Locale of the Study}

The study was conducted at Telafas National High School in the Municipality of Columbio, Province of Sultan Kudarat, Philippines. Telafas National High School is a public high school specifically located in the municipality of Columbio, in the province of Sultan Kudarat, and the Region of XII - South Cotabato, Cotabato, Sultan Kudarat, Sarangani and General Santos City (SOCCSKSARGEN), that was established on January 01, 2002.

\subsection{Participants of the Study}

The researchers utilized the Grade 8 students of Telafas National High School, Columbio, Sultan Kudarat who were enrolled during the School Year 2018-2019. Thirty-three students were included in the control group, and another thirty-five students for the experimental group regardless of 
sex and section selected randomly from the four sections and grouped as one for the whole duration of the conduct of the study. This also included experts in the field of language teaching that validated the instructional materials being used.

\subsection{Sampling Technique}

The selection of respondents was based on random sampling. The researchers chose two groups from the four sections of Grade 8 in Telafas National High School that represented the control and experimental groups. 33 students were included in the control group and 35 students in the experimental group which was randomly selected from four sections using the fish ball method. The control group which was taught using the book, board and paper method and the other group utilized the communicative approach in teaching the Afro-Asian Literature.

\subsection{Data Gathering Instrument}

Survey questionnaires rated by the experts in language teaching was used in gathering the data needed in the study. It consisted items that measured the acceptability of communicative approach in teaching Afro-Asian in terms of content, relevance, and instructional quality which was copied and modified from [1] and interpreted using the following scale:

\subsection{Interpretation}

A researchers-modified activity which is related to the text given in the Learning Materials of Grade 8 was used in the items that measured students' performance in Afro-Asian Literature. Unified rubrics was used as a tool in measuring the students' performance for every activity that was retrieved from [15]

Table 1. Interpretation Scale on the Acceptability of Intructional Material

\begin{tabular}{lll}
\hline $4.21-5.00$ & Very Highly Acceptable & $90-100 \%$ observed and implemented \\
$3.40-4.20$ & Highly Acceptable & $80-89 \%$ observed and implemented \\
$2.61-3.40$ & Acceptable & $70-79 \%$ observed and implemented \\
$1.81-2.60$ & Less Acceptable & $50-69 \%$ observed and implemented \\
$1.00-1.80$ & Not Acceptable & $30-49 \%$ observed and implemented \\
\hline
\end{tabular}

\subsection{Interpretation}

Table 2. Data Interpretation on the Pre-Test and Post-Test Results

\begin{tabular}{ll}
\hline Grading Scale & Description \\
$90-100$ & Outstanding (O) \\
$85-89$ & Very Satisfactory (VS) \\
$80-84$ & Satisfactory (S) \\
$75-79$ & Fairly Satisfactory (FS) \\
Below 75 & Did Not Meet Expectations (DNME) \\
\hline
\end{tabular}

\subsection{Data Gathering Procedure}

The researchers sought first the support of the Language experts to validate the developed module assure its acceptability in terms of its content, relevance and instructional quality. Then, letters were sent to the Schools Division Superintendent of Sultan Kudarat and to the principal of Telafas National High School seeking permission to use the Grade 8 students as participants of the study on "Communicative Approach in Teaching Afro-Asian Literature." The administration of the questionnaire was done personally by the researchers so that proper responses were elicited. Retrieval of the questionnaire was done right after the respondents answered the questionnaire. The data was consolidated and interpreted.

\subsection{Statistical Treatment and Data Interpretation}

The information gathered by the researchers was analyzed through the use of frequency count, percentage, mean and ttest. The frequency count, percentage, and mean was used to describe the acceptability of the tool being used in terms of content, relevance, and instructional quality. T-test was used to analyze the significant difference between the control group and experimental group mean gain score in their Afro-
Asian Literature performance.

\section{Results and Discussion}

\subsection{Acceptability of Instructional Module with Integhration of Communicative Approach}

The content, relevance, and instructional quality of the material were validated by the experts and were determined and interpreted using grand mean score. Results were presented in Table 3.

Table 3. Acceptability of Instructional Module with Integhration of Communicative Approach.

\begin{tabular}{lll}
\hline Indicators & Mean & Interpretation \\
\hline Content & 3.90 & Highly Acceptable \\
Relevance & 3.85 & Highly Acceptable \\
Instructional Quality & 3.83 & Highly Acceptable \\
Over-all Mean & 3.86 & Highly Acceptable \\
\hline
\end{tabular}

Source: [1].

Table 3 shows that the instructional module used in this study is highly acceptable in terms of content with a mean of 3.90 , highly acceptable in relevance obtaining a mean of 3.85 , and highly acceptable instructional quality with a mean of 3.83. It also reveals that with an over-all mean of 3.86, the instructional module being utilized in this study is highly acceptable which is interpreted as $80-89 \%$ of the indicators are observed and implemented. These results are supported by the study of [2] stating that "there is a strong positive link between instructional resources and academic performance". He also added that "schools possess more instructional resources performed better than the schools which had less instructional resources." 


\subsection{Performance of Control Group in Afro-Asian Literature}

The performance of the control group in Afro-Asian
Literature was determined using grand mean of their pre-test and post-test and interpreted using the transmuted grades based on [5]. The results is shown in Table 4.

Table 4. Performance of Control Group in Afro-Asian Literature.

\begin{tabular}{|c|c|c|c|c|c|c|}
\hline Lessons & $\begin{array}{l}\text { Pre-test Scores } \\
\text { (Mean) }\end{array}$ & $\begin{array}{l}\text { Transmuted } \\
\text { Grade }\end{array}$ & Verbal Rating & $\begin{array}{l}\text { Post-test Scores } \\
\text { (Mean) }\end{array}$ & $\begin{array}{l}\text { Transmuted } \\
\text { Grade }\end{array}$ & Verbal Rating \\
\hline Lesson 1 & 5.48 & 65.00 & $D N M E$ & 16.48 & 79.00 & $F S$ \\
\hline Lesson 2 & 4.48 & 64.00 & $D N M E$ & 14.00 & 74.00 & $F S$ \\
\hline Lesson 3 & 5.70 & 65.00 & $D N M E$ & 16.06 & 77.00 & $F S$ \\
\hline Lesson 4 & 5.67 & 65.00 & $D N M E$ & 15.09 & 75.00 & $F S$ \\
\hline Lesson 5 & 5.33 & 65.00 & $D N M E$ & 14.64 & 74.00 & $F S$ \\
\hline Lesson 6 & 5.21 & 65.00 & $D N M E$ & 14.06 & 74.00 & $F S$ \\
\hline Lesson 8 & 4.76 & 64.00 & $D N M E$ & 15.45 & 76.00 & $F S$ \\
\hline Lesson 9 & 5.30 & 65.00 & $D N M E$ & 14.91 & 74.00 & $F S$ \\
\hline Lesson 10 & 6.27 & 66.00 & $D N M E$ & 15.09 & 75.00 & $F S$ \\
\hline $\begin{array}{l}\text { Over-All } \\
\text { Mean }\end{array}$ & 5.38 & 64.90 & DNME & 15.33 & 75.90 & FS \\
\hline
\end{tabular}

Note: Legend: DNME- Did Not Meet Expectation; S- Satisfactory; FS- Fairly Satisfactory.

Table 4 presents that the control group's performance did not meet the expectation in Afro-Asian Literature in their pretest results that obtained a grand mean of 5.38 with the transmuted grade of 64.90 . On the other hand, the control group has a fairly satisfactory performance with a grand mean of 15.33 transmuted into 75.90 except for lesson seven that obtained a mean of 17.55 transmuted as 81.00 and described as satisfactory. The findings were supported by the study of [6] that those good teachers, who are always on the alert for methods and instructional materials will make learning meaningful. With the wise selection and use of a variety of instructional materials or audio-visual materials, experiences may be provided to develop understanding. Results even argue that "language acquisition is still far from over at this point as there is still complex grammar to acquire and new linguistic meanings to learn." [7]

\subsection{Performance of Experimental Group in Afro-Asian Literature}

Grand mean was used to determine the performance of the experimental group in Afro-Asian, which is transmuted and interpreted using [5]. Table 5 shows the results.

Table 5. Performance of Experimental Group in Afro-Asian Literature.

\begin{tabular}{|c|c|c|c|c|c|c|}
\hline Lessons & $\begin{array}{l}\text { Pre-test Scores } \\
\text { (Mean) }\end{array}$ & Transmuted Grade & Verbal Rating & $\begin{array}{l}\text { Post-Test Scores } \\
\text { (Mean) }\end{array}$ & Transmuted Grade & Verbal Rating \\
\hline Lesson 1 & 4.71 & 64.00 & DNME & 21.00 & 90.00 & $\mathrm{O}$ \\
\hline Lesson 2 & 5.14 & 65.00 & DNME & 20.34 & 88.00 & VS \\
\hline Lesson 3 & 4.94 & 64.00 & DNME & 21.51 & 91.00 & $\mathrm{O}$ \\
\hline Lesson 4 & 5.29 & 65.00 & DNME & 21.11 & 90.00 & $\mathrm{O}$ \\
\hline Lesson 5 & 5.29 & 65.00 & DNME & 20.74 & 89.00 & VS \\
\hline Lesson 6 & 5.14 & 65.00 & DNME & 19.89 & 87.00 & VS \\
\hline Lesson 7 & 5.26 & 65.00 & DNME & 23.29 & 95.00 & $\mathrm{O}$ \\
\hline Lesson 8 & 6.00 & 66.00 & DNME & 20.60 & 89.00 & VS \\
\hline Lesson 9 & 5.31 & 65.00 & DNME & 22.51 & 93.00 & $\mathrm{O}$ \\
\hline Lesson 10 & 5.20 & 65.00 & DNME & 21.46 & 91.00 & $\mathrm{O}$ \\
\hline $\begin{array}{l}\text { Over All } \\
\text { Mean }\end{array}$ & 5.23 & 64.90 & DNME & 21.25 & 90.30 & Outstanding \\
\hline
\end{tabular}

Note: Legend: DNME- Did Not Meet Expectation; O- Outstanding; VS- Very Satisfactory

The results reveal that the experimental group did not meet the expectation in their pre-test having a grand mean of 5.23 transmuted into 64.90. On the other hand, their post test result is relatively higher with a grand mean of 21.25 transmuted into 90.30 which is described as outstanding. The result was supported by the findings of [4], that 'teachers' attribute has a significant relationship with students' academic performance." He further explained that "such attributes include teachers' knowledge of the subject matter, communication ability, emotional stability, good human relationship and interest in the job."

This further refelected that "Communicative Language Teaching misapprehensions include beliefs that the approach involves the exclusive focus on meaning, no exclusive focus on learner errors, listening and speaking practice only, and avoidance of the learner's mother tongue." [9] 


\subsection{Analysis Between the Mean Gain Score of Control and Experimental Group}

Table 6. Analysis Between the Mean Gain Score of Control and Experimental Group.

\begin{tabular}{llllll}
\hline Group & $\mathbf{n}$ & Mean ain Scores & t-computed & t-critical & Interpretation \\
\hline Control & 33 & 9.96 & 1.997 & 1.73 & Significant \\
Experimental & 35 & 16.02 & & & \\
\hline
\end{tabular}

*.05 level of significance.

Table 6 shows the t-test analysis on the performance of control group and experimental group in Afro-Asian literature. The results indicate that there is a significant difference between the mean gain scores of the control and experimental group which are equivalent to 9.96 and 16.02 respectively. It can be gleaned that the t-computed of 1.997 is higher than the t-critical value of 1.73 at 0.05 level of significance. Thus, there is sufficient evidence to reject the null hypothesis which states that "There is no significant difference between the performance of control group and experimental group in AfroAsian Literature in their mean gain score." Based from the result, it can be inferred that the experimental group improved better than the control group. Therefore, the communicative approach in teaching Afro-Asian Literature contributed much to the performance of grade 8 students compared to the use of chalk and board in teaching.

The results are further elaborated that "most learners have other and far less specific and predictable purposes, and it does not seem reasonable to impose such ESP objectives on them, especially since they are unlikely to attain them anyway because what they need is what is actually referred to as EGP - English for General Purposes - English that can be adapted to any purpose and made appropriate to any context." [14]

\section{Summary}

Generally This study was done to test the acceptability of the Communicative Approach in teaching Afro-Asian Literature and the student's performance. There were 68 respondents composed of 33 students for the control group and 35 students for the experimental group. The summary of findings was as follow:

The acceptability of instructional module used in the test of communicative approach in teaching is highly acceptable concerning the content, relevance and instructional quality that yield an over-all mean of 3.86 signify that $80-89 \%$ of the indicators were observed and implemented.

The performance of the control group did not meet the expectation in their pre-test which obtained a grand mean of 5.38 and with a transmuted rating of 64.90 and performed fairly satisfactory in their post-test with a grand mean of 15.33 transmuted into 75.90 .

The experimental group's performance did not meet the expectation in their pre-test with a grand mean of 5.23 transmuted into 64.90 and performed outstanding in the posttest which obtained an over-all mean of 21.25 with a transmuted rating of 90.30 .

There is a significant difference between the mean gain score of the control group which is 9.96 and the experimental group with a gain of 16.02 since the t-computed value of 1.997 is greater than $t$-critical of 1.73 .

\section{Conclusion}

In light of the findings derived from this study, these conclusions were deduced:

The communicative learning module used in teaching Afro-Asian Literature is highly acceptable in terms of its content, relevance and instructional quality. The control group performance did not meet the expectation in their pretest and fairly satisfactory in their post-test. The experimental group performance did not meet the expectations in the pretest and obtained an outstanding performance in the post-test. There is a significant difference between the mean gain score of the control group and experimental group. The researcher therefore concluded that the utilization of the Communicative Approach in teaching Afro-Asian Literature is useful to the performance of Grade 8 students.

\section{Recommendations}

Based on the findings of the study, the following were recommended:

1. Teachers may consider the Communicative Approach in teaching literature so that learners could be involved in real communication situations and this would allow them to use the language with their natural strategies.

2. The Department of Education (DepEd) may revisit and consider the inclusion of more communicative activities in doing the learning modules for the students to further enhance the communication skills of the learners.

3. The instructional module may be elevated into very highly acceptable by including more learning tasks that are related to the necessary contents to develop skills that are expected among students that would help them to meet further expectations for the set competencies by the Department of Education (DepEd).

\section{References}

[1] Abelito, J. T. (2018). Adopt-A-Student Program and Reading Performance of Grade 7 of Maligaya National High School. Unpublished Master's Thesis. Sultan Kudarat State University, ACCESS, EJC Montilla, Tacurong City, Sultan Kudarat, Philippines. 
[2] Adeogum, A. A. (2001). The Principal and the Financial Management of Public Secondary Schools in Osu State. Journal of Educational System and Development. Retrieved: September 16, 2018.

[3] Artess, J. (2010). "How Adults Really Learn-or What We Think We Know About How They Learn!" Centre for Learning aqnd Teaching. Manchester Metroploitan University, United Kingdom. Retrieved: September 24, 2018.

[4] Bangbade, J. O. (2004). "Effects of Subject Matter Knowledge in the Teaching and Learning of Biology and Physic". Teaching and Teacher Education: 109-102. Retrieved: August 25,2018 .

[5] DepEd Order No. 8 (2015). "Policy Guiedelines on Classroom Assessment for the $\mathrm{K}$ to 12 Basic Education Program". Retrieved: July 8, 2020.

[6] Diana, S. (2014). Communicative Language Teaching and Its Misconceptions About the Practice in English Language Teaching (ELT). Journal Bahasa \& Sastra. Retrieved: August 23,2018

[7] Karmiloff, K., \& Karmiloff-Smith, A. (2002). Pathways to language: from fetus to adolescent. Cambridge, Mass.: Harvard University Press.
[8] Kirkpatrick, A. (2010). English as a lingua franca in ASEAN: A multilingual model. Hong Kong: Hong Kong University Press.

[9] Mohammad, N. I. (2012). Communicative approach: Some misapprehensions. International Journal of Academic Research in Business and Social Sciences. 2 (1): 211-219.

[10] Montrul, S. (2010). Current Issues in Heritage Language Acquisition. Annual Review of Applied Linguistics, 30, 3-23.

[11] Moon, Jennifer A. (2004). A Handbook of Reflective and Experiential Learning: Theory and Practice. Routledge Falmer. London, United Kingdom.

[12] Richards, J. C. (2006). Communicative Language Teaching Today, Cambridge University Press. New York, The United States of America.

[13] Savignon, S. J. (2003). Teaching English As Communication: A Global Perspective. World Englishes, 22 (1), 55-66. Retrieved: September 1, 2018.

[14] Seidlhofer, B. (2011). Understanding English as a lingua franca. Oxford: Oxford University Press.

[15] https://www.dcs.k12.oh.us/cms/lib07/OH16000212/Centricity/ Domain/104/Rubric_Speaking.pdf. Retrieved: August 10, 2018. 